\title{
STUDY REGARDING THE PLANNING PROCESS IN PHYSICAL EDUCATION AND SPORTS
}

\author{
Marcel POMOHACI \\ marcelpomohaci@yahoo.com \\ Ioan Sabin SOPA \\ sopa_sabin@yahoo.com \\ “LUCIAN BLAGA” UNIVERSITY, SIBIU, ROMANIA
}

\begin{abstract}
The planning process in every domain represents the first fundamental process; also, the physical and sport activity needs meticulous planning of the activity so that the density of the physical lessons and the efficiency to be at a high level. Our study is based on a questionnaire undertaken by ten physical education teachers from Sibiu City regarding planning the PE activity, the efficiency of the methods used in planning the activity, and other essential problems that occurred in the process of planning the PE activity. The research found out that the planning activity must be changed and adapted to children's new needs in teachers' opinion. Also, the documents are often too many and sometimes useless occupying teachers' time and not being so efficient. The research conclusions are that planning the $P E$ activity is a significant activity and new ways of planning and new curriculum should be added, and many inefficient documents should disappear so that the teachers' time is used more efficiently.
\end{abstract}

\section{KEYWORDS:}

Planning process, physical education, teaching efficiency

\section{Introduction}

There is a growing interest in the role of $\mathrm{PE}$ in training young people for the demands and difficulties of daily life (Society of Health and Physical Educators, 2014). In response to a worldwide PE survey, Hardman et al. (2014) observed that personal and social growth is one of the leading and most widely quoted European PE systems (Opstoel et al., 2020).

The planning activity is often found in different professions. In most situations, plans are correctly understood and used (Stănescu, 2013).

According to Goudas and Giannoudis (2008), one of the reasons why PE and sport are basic settings for acquiring these skills is transferring these skills to other life areas. For example, in PE and sports, children may do so under the right pedagogical conditions (Bailey et al., 2009), learn how to solve challenges and connect and function as a team, which are qualities that would still be used in 
everyday life, for example, at home or work. Planning is a challenging activity for Physical Education (PE) teachers that can create doubts and uncertainty among novices (Sáenz-López, Almagro, \& Ibáñez, 2011) and seasoned teachers alike (Viciana \& Zabala, 2004). Many factors affect the planning process, and considering them all at the same time during the decisionmaking process is a challenge for teachers, particularly when they are new or have no experience in teaching PE (Viciana \& Mayorga-Vega, 2013). Plans express a conceptual approach to the activity content (Ryan, 2011) and give the premises of an efficient activity (Berke \& Godschalk, 2009).

This activity of planning the physical education activity requires minacious work and lots of documents, which often leads to the creation of some formal documents that are not very useful to the teachers unless they are presented on occasion the school inspection (Cristea et al., 2006; Bocoș \& Jucan, 2008).

One of the necessary skills of physical education teachers is planning (Mosston \& Ashworth, 2008). This is where the collection and configuration of learning strategies and techniques starts. The arrangement of learning activities is not a result of improvisation or an excess of imagination (Jones et al., 2003). The specialty literature provides little information about the relation between these forms of curriculum, namely the official one created during the lessons. Some authors mention a relatively frequent phenomenon related to interpreting the official documents normalizing the physical education teachers' activity (Stănescu, 2009).

Many of the suggestions in the literature aim to instruct PE teachers in the preparation of different topics, to suggest unique teaching units, many kinds of classes, to combine different curricular contents, or even to propose several tasks relevant to a particular topic of PE (Fey, 2011; Redmon, Foran, \& Dwyer, 2010; Salvador, Chiva, \& Fazio, 2016). It is also essential to provide effective solutions for both teachers and teachers to promote PE preparation and, ultimately, the distribution of PE to schools. Since several contributions have established a range of guidelines for PE preparation and intervention (Bulger \& Housner, 2009; Liersch et al., 2011), unfortunately, as far as we know, there are no systematic planning perspectives that incorporate, from a systemic viewpoint, all the aspects that affect the planning decision-making method (Vicina \& Mayorga-Vega, 2018).

From the point of view of the planning process in physical education and sports, several articles discussed the planning part of agility training (Szabo et al., 2020, Sopa \& Szabo, 2015), planning the development of strength (Tulbure et al., 2020) and planning in the game of volleyball (Szabo, 2014; Szabo, 2015a; Szabo, 2015b; Szabo \& Sopa, 2015; Szabo et al., 2019). We came across an article that dealt with even the planning part in stress management among students (Popa et al., 2020) and one that dealt with the sports pedagogical planning part (Ardelean et al., 2020).

\section{Objectives of the research}

The objectives of this paper, subordinated to the fulfillment of its objectives and tasks, as well as the verification of the general hypothesis, concerned the following fundamental aspects:

a) Studying the programs of Physical Education and sports at the level of high school education;

b) The level of the approach of the topic in the specialized works (physical education and sports);

c) Understanding and applying the new methodology of designing the didactic approach in the activity of Physical Education and sports;

d) Acquiring the prominent conceptual and methodological landmarks of the new National Curriculum; 
e) Preparation of annual planning;

f) Designing the annual strategy of the learning units on different age levels;

g) Designing learning units derived from the contents of Physical Education and sports programs;

h) Preparation of examples of lesson plans (teaching projects);

i) Establishing research methods and techniques;

j) Designing the questionnaire applied to specialists in the field of Physical Education and sports;

k) Analysis of the questionnaire and centralization of the results;

1) Analysis and interpretation of results;

m) Formulation of the conclusions and proposals of the study.

\section{Research method}

In the research made for solving and fulfilling the tasks and objectives of the present study, we used the questionnaires primary investigation tool, with the help of which we made and verified the general hypotheses and the working ones.

The questionnaire designed and addressed to specialists in the field of physical education and school sports contains several 12 items according to the type of answers, these being structured as follows:

a) questions with alternative answers: 11 (graphic scale with 5 degrees of intensity)

b) questions with free answers: 1 .

\section{Research protocol}

\subsection{Research hypothesis}

The general hypothesis was the following: If the didactic activity of physical education and sports meets all the current conditions of this discipline and follows the methodology of applying the new system and curriculum, then the efficiency of the instructive-educational process can be significantly increased.

\section{research \\ 4.2. Period and location of the}

The research took place in Sibiu county, Romania, and started on 01.09.2020 and finished on 01.10.2020. The research included several teachers from different schools from Sibiu with different levels of experience and teaching degrees.

\subsection{Subjects of the research}

The questionnaire was applied to a sample of 10 specialists in physical education and sports. In 8 of the cases, the direct questionnaire was applied, and in 2 cases, the postal questionnaire. The percentage of non-responses in the case of the postal questionnaire was $0 \%$.

The sample of 10 specialists is presented according to different criteria as follows:

a) according to the criterion of the level of the educational unit where they carry out their didactic activity: all the ten specialists are employed in high schools with grades IX-XII;

b) according to the environmental criterion: all the ten specialists carry out their activity in the urban environment;

c) according to the sex criterion: 7 males and three females;

d) according to the criterion of the didactic degrees obtained: 3 specialists with didactic degree II, five specialists with the didactic degree I, and two specialists with finalized. 


\subsection{The research questionnaire}

Table no. 1

The research questionnaire

\begin{tabular}{|c|c|c|c|c|c|}
\hline Questionnaire items and scale & $\begin{array}{c}\text { Strong } \\
\text { agreement }\end{array}$ & $\begin{array}{c}\text { Good } \\
\text { agreement }\end{array}$ & Agreement & $\begin{array}{c}\text { Low } \\
\text { agreement }\end{array}$ & $\begin{array}{l}\text { Don't } \\
\text { agree }\end{array}$ \\
\hline \multicolumn{6}{|c|}{$\begin{array}{l}\text { Item 1: Do you consider didactic design an } \\
\text { activity that can improve the instructive- } \\
\text { educational process? }\end{array}$} \\
\hline \multicolumn{6}{|l|}{$\begin{array}{l}\text { Item 2: Do you consider it essential to } \\
\text { implement the novelties in didactic design } \\
\text { and the annual revision of the design } \\
\text { documents? }\end{array}$} \\
\hline \multicolumn{6}{|l|}{$\begin{array}{l}\text { Item 3: Does the observance of the didactic } \\
\text { design's general requirements influence the } \\
\text { quality of the designed documents? }\end{array}$} \\
\hline \multicolumn{6}{|l|}{$\begin{array}{l}\text { Item 4: Do you consider the physical } \\
\text { education and sports curriculum a } \\
\text { mandatory landmark in the didactic design } \\
\text { activity? }\end{array}$} \\
\hline \multicolumn{6}{|l|}{$\begin{array}{l}\text { Item 5: How much does the content } \\
\text { provided by the current physical education } \\
\text { and sports programs contribute to achieving } \\
\text { the skills needed by each student? }\end{array}$} \\
\hline \multicolumn{6}{|l|}{$\begin{array}{l}\text { Item 6: In your opinion, are the annual } \\
\text { staggering and the design of the learning } \\
\text { units the only necessary documents for } \\
\text { didactic design? }\end{array}$} \\
\hline \multicolumn{6}{|l|}{$\begin{array}{l}\text { Item 7: How important do you find calendar } \\
\text { planning? }\end{array}$} \\
\hline \multicolumn{6}{|l|}{$\begin{array}{l}\text { Item 8: To what extent are you concerned } \\
\text { about the correct and efficient design of } \\
\text { learning units? }\end{array}$} \\
\hline \multicolumn{6}{|l|}{$\begin{array}{l}\text { Item 9: To what extent do you consider that } \\
\text { the lesson of physical education and sports is } \\
\text { in an interdependent relationship with the } \\
\text { learning units? }\end{array}$} \\
\hline \multicolumn{6}{|l|}{$\begin{array}{l}\text { Item 10: Does the current didactic design } \\
\text { methodology offer possibilities to manifest } \\
\text { the specialist's autonomy in physical } \\
\text { education and sports? }\end{array}$} \\
\hline \multicolumn{6}{|l|}{$\begin{array}{l}\text { Item 11: Do you consider the current way of } \\
\text { didactic design more efficient than the one } \\
\text { used before? }\end{array}$} \\
\hline $\begin{array}{l}\text { Item 12: Do you have any proposals to } \\
\text { improve the education law in this area? }\end{array}$ & & & & & \\
\hline
\end{tabular}

\section{Results}

Following the centralization of the results and the percentage calculation performed, the following are significant:

At the first item: The specialists in the field of physical education and sports consider that at present, as a consequence of the application in education of the new National Curriculum as well as of the didactic design methodology, it is a condition that can contribute to a decisive weight to the efficiency of the instructiveeducational process. 


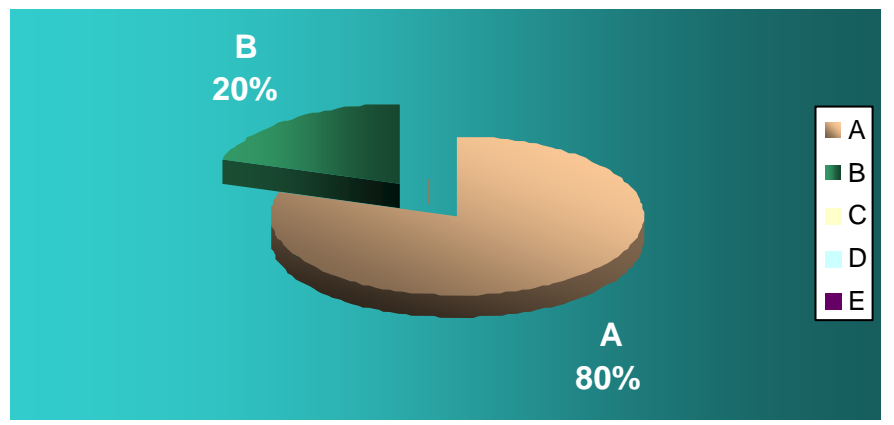

Figure no. 1: Graphical representation of the answers to the first item of the questionnaire: Do you consider didactic design an activity that can improve the instructive-educational process?

At the second item: The interest shown by specialists for the novelties in the field of didactic design and the annual revision of the design documents has become a constant in the developed activity.

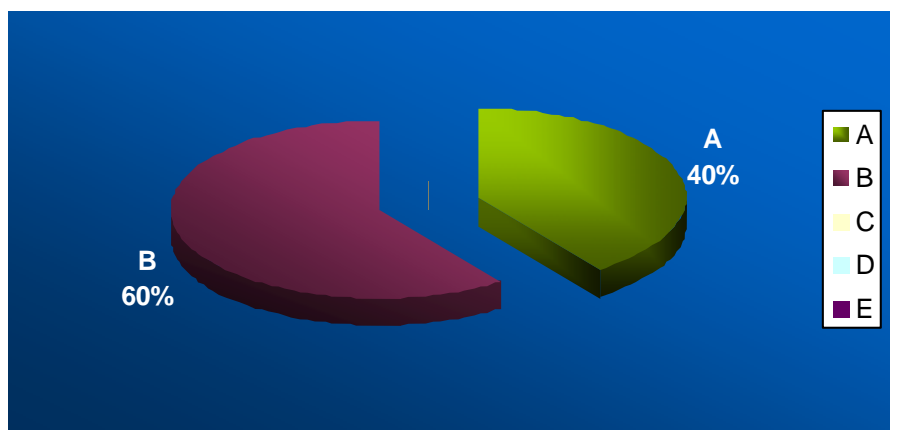

Figure no. 2: Graphical representation of the answers to the $2^{\text {nd }}$ item of the questionnaire:

Do you consider it essential to implement the novelties in didactic design and the annual revision of the design documents?

At the $3^{\text {rd }}$ item: The didactic design requirements formulated by the documents must be made following the general in force.

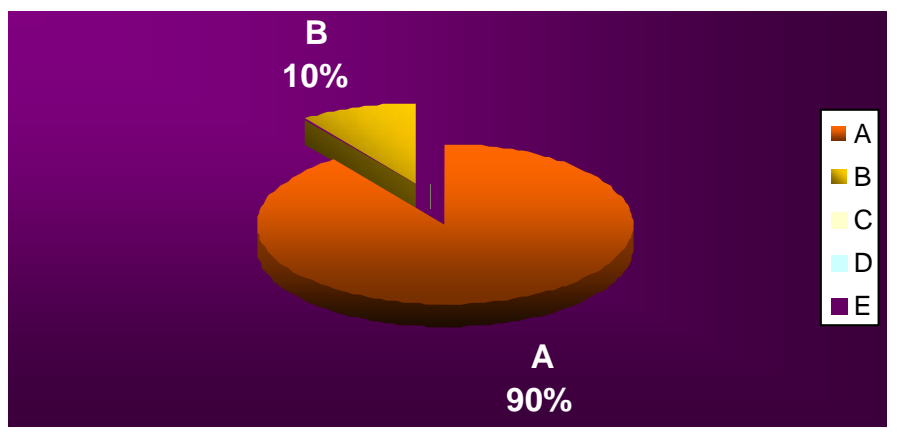

Figure no. 3: Graphical representation of the answers to the questionnaires $3^{\text {rd }}$ item:

Does the observance of the didactic designs general requirements influence the quality of the designed documents? 
The $4^{\text {th }}$ item of the questionnaire: The physical education and sports programs (documents that can be perfected in time) constitute all the investigation specialists a mandatory landmark in the didactic design activity.

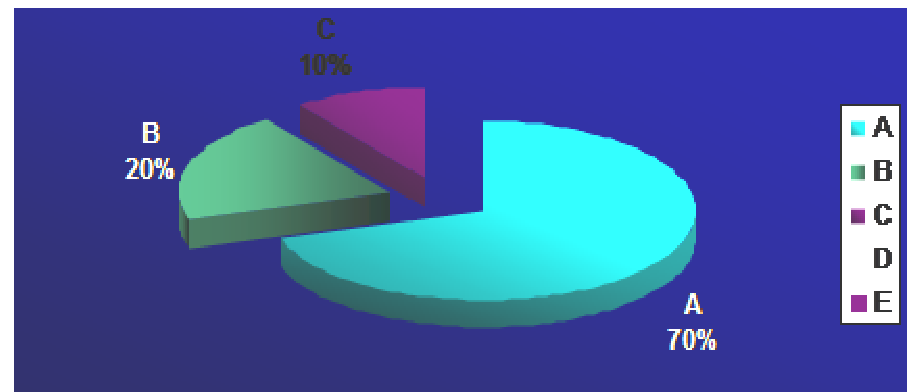

Figure no. 4: Graphical representation of the answers to the questionnaire's $4^{\text {th }}$ item: Do you consider the physical education and sports curriculum a mandatory landmark in the didactic design activity?

Regarding the $5^{\text {th }}$ item of the programs make the efficient fulfillment of questionnaire: The contents provided by the the framework objectives and the specific current physical education and sports competencies.

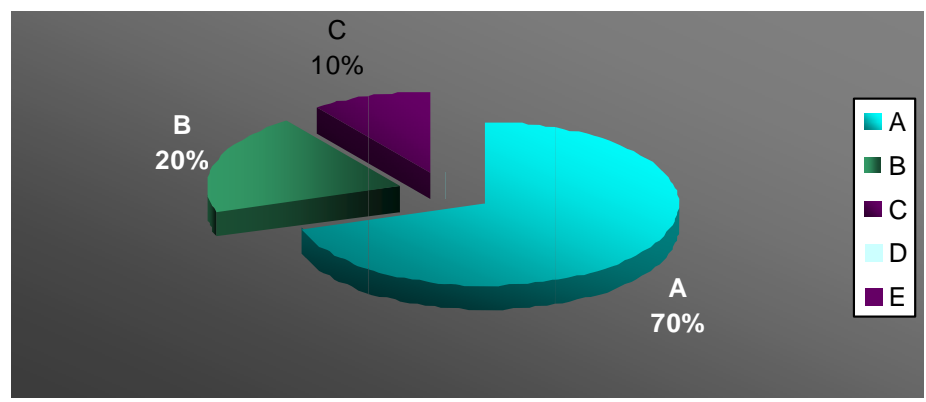

Figure no. 5: Graphical representation of the answers to the $5^{\text {th }}$ item of the questionnaire:

How much does the content provided by the current physical education and sports programs contribute to achieving the skills needed by each student?

At the $6^{\text {th }}$ item of the questionnaire: concretizes the entire conception of didactic The learning units' annual staggering design of the specialists in the field. design represents particular importance that

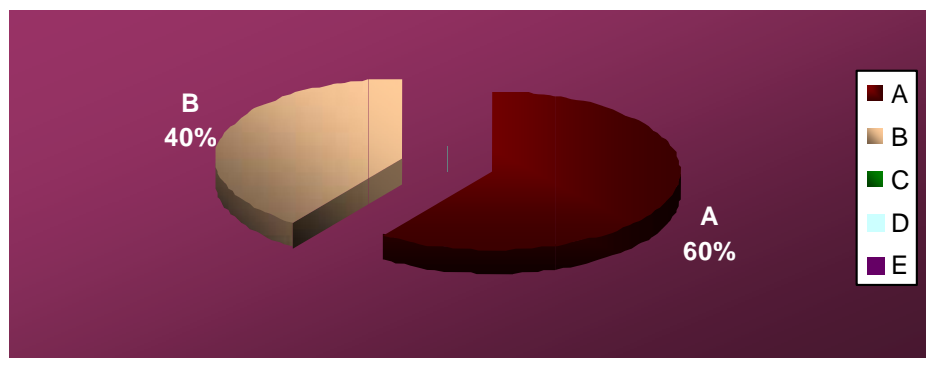

Figure no. 6: Graphical representation of the answers to the $6^{\text {th }}$ item of the questionnaire:

In your opinion, are the annual staggering and the design of the learning units the only necessary documents for didactic design? 
The $7^{\text {th }}$ item of the questionnaire: The semiannual calendar planning has a unique utility in the development with good results of the instructive-educational process.

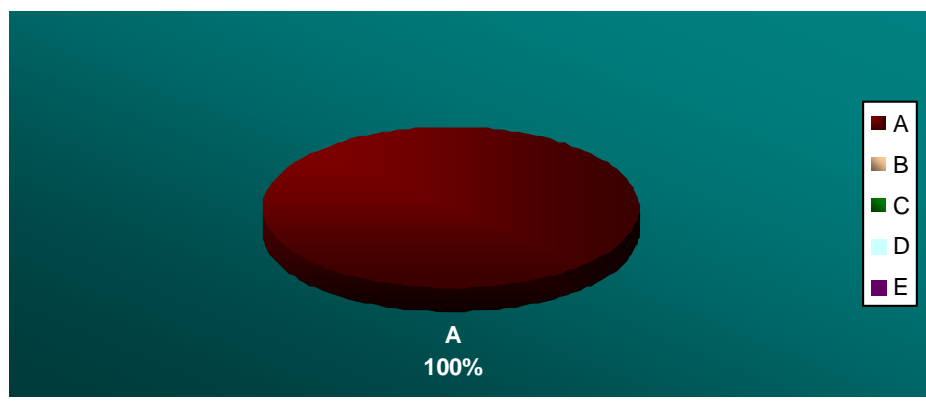

Figure no. 7: Graphical representation of the answers to the questionnaire's $7^{\text {th }}$ item: How important do you find calendar planning?

The correct and efficient design of the learning units must represent a document with high stability that will make a decisive contribution to fulfilling the specific competencies provided by the specialized programs.

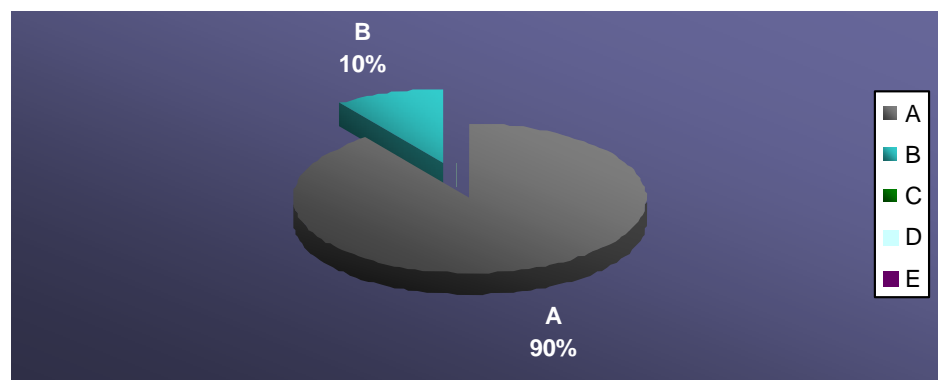

Figure no. 8: Graphical representation of the answers to the $8^{\text {th }}$ item of the questionnaire: To what extent you are concerned about the correct and efficient learning units' design?

The $9^{\text {th }}$ item of the questionnaire: The current relationship between the physical education and sports lesson (common core lesson) and the designed learning units is a good premise for improving the instructiveeducational process's quality.

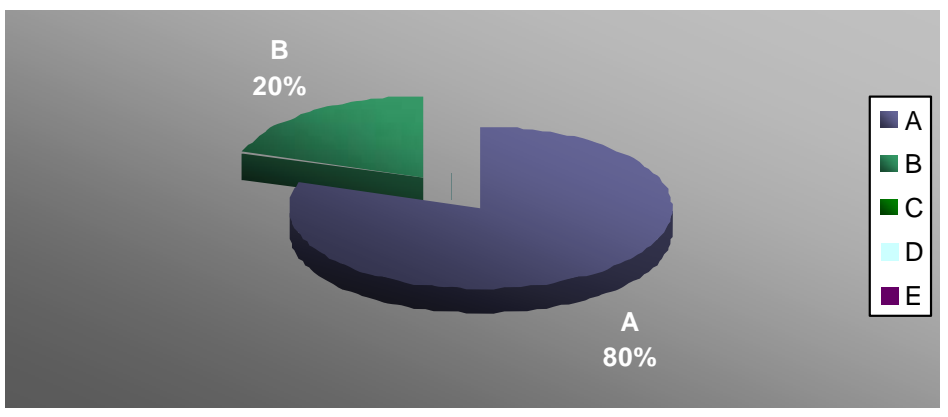

Figure no. 9: Graphical representation of the answers to the $9^{\text {th }}$ item of the questionnaire:

To what extent do you consider that the lesson of physical education and sports is in an interdependent relationship with the learning units? 
At item 10: The current relationship between the physical education and sports lesson (common core lesson) and the designed learning units is a good premise for improving the instructive-educational process's quality.

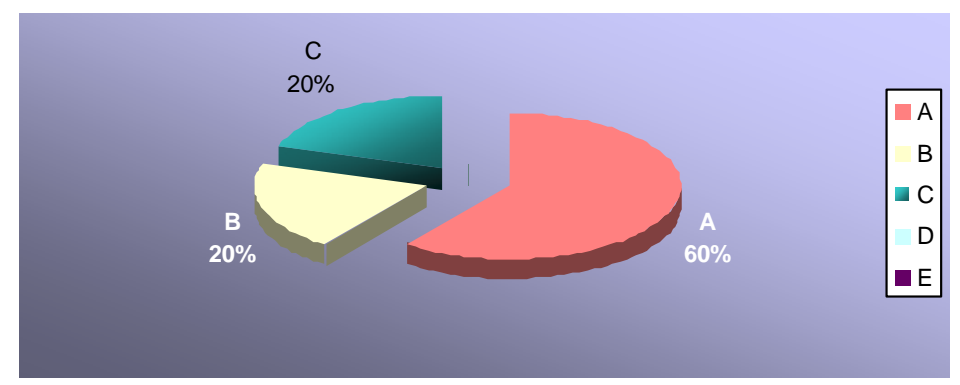

Figure no. 10: Graphical representation of the answers to the $10^{\text {th }}$ item of the questionnaire:

Does the current didactic design methodology offer possibilities to manifest the specialist's autonomy in physical education and sports?

At item 11: The specialists in the field consider the current didactic design method more useful than the one used previously.

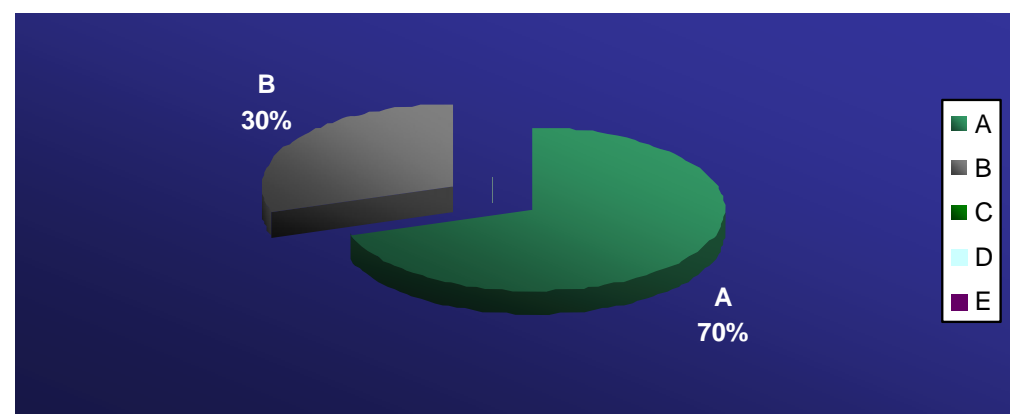

Figure no. 11: Graphical representation of the answers to the $11^{\text {th }}$ item of the questionnaire:

Does the current didactic design methodology offer possibilities to manifest the specialist's autonomy in physical education and sports?

\section{Discussions}

Following the registration of the results and the calculation of the percentages, the following results:

1. To the first question, related to the probability that the didactic design represents an activity that can improve the instructive-educational process, the following situation is observed: 8 responses from a total of 10 ( $80 \%$ of the total) strongly agree with the affirmation that the didactic design is an activity that can improve the instructive - educational process, two responses from a total of $10(20 \%$ from the total) have a good agreement with the affirmation. Other scientific research concluded that teachers must be focused on the curriculum goals, not particularly on its content (Stănescu, 2013).

2. At the second item of the questionnaire that asked about the importance of implementing the novelties in the field of didactic design as well as the annual revision of the design documents, it was found the following: 6 responses from a total of 10 (60\% from the total) strongly agreed with the affirmation and also four respondents (40\% from the total) had a good agreement with the affirmation. 
Regarding the third item of the questionnaire that refers to the conditioning of the observance of the general requirements of the didactic design and if they influence the quality of the designed documents, the respondents of the sample answered as follows: 9 out of 10 respondents, representing $90 \%$ from the total, strongly agreed with the statement and 1 out of 10 , representing $10 \%$ from the total, had a good agreement with the question.

At the $4^{\text {th }}$ item of the questionnaire that referred to the consideration of the physical education and sports program as a mandatory landmark in the didactic design activity, the respondents offered the following answers: 7 answers (70 \% from the total) that strongly agreed with the affirmation, two respondents $(20 \%$ from the total) have a right agreement level, and one respondent (representing $10 \%$ from the total) agreed with the affirmation.

Regarding the $5^{\text {th }}$ item of the questionnaire that referred to the contents provided by the current physical education and sports programs contribute to the achievement of the necessary competencies for each student, it was obtained the following answers: 7 respondents, representing $70 \%$ of the total respondents, strongly agreed with the statement, three respondents, representing $30 \%$ from the total respondents, had a good agreement with the statement.

In the $6^{\text {th }}$ item of the questionnaire regarding the annual staggering and the design of the learning units as the only necessary documents for didactic design, the following answers were obtained: 6 respondents $(60 \%$ from the total) strongly agreed with the affirmation, and four respondents (representing $40 \%$ from the total) had a good agreement with the statement. Also, other scientific research conclusions showed that among the planning documents, teachers prefer only two: the annual plan and the semester plan (Stănescu, 2013).

The $7^{\text {th }}$ item of the questionnaire regarding how important they find the calendar planning; the ten interviewed specialists offered the following answers: all ten respondents strongly agreed with the current statement.

Regarding the $8^{\text {th }}$ item of the questionnaire that enquired about the concern of specialists for proper design and effective learning units, they gave the following answers: 9 respondents (representing $90 \%$ of the total) strongly agreed with the statement, and only 1 (representing $10 \%$ from the total) had a good agreement with the affirmation.

The $9^{\text {th }}$ item of the questionnaire treated the problem of physical education and sports lesson and the interdependent relationship with the learning units, and we received the following answers: 8 answers (representing $80 \%$ from the total) with a strong agreement and two answers (representing $20 \%$ from the total) had a fair agreement.

At the $10^{\text {th }}$ item of the questionnaire regarding current didactic design methodology and if it offers possibilities to manifest the autonomy of the specialist in physical education and sports, the following answers were received: 6 answers (representing $60 \%$ of the total) strongly agreed with the statement, two respondents (representing $20 \%$ from the total) had a satisfactory agreement, and two respondents agreed with the current statement.

At the last item of the questionnaire regarding the efficiency of the current way of didactic design compared to the one used previously; the specialists offered the following answers: 7 respondents, representing $70 \%$ of the total, strongly agreed with the statement, and three respondents had a good agreement with the affirmation. 


\section{Conclusions}

The development of this study highlights the importance of didactic design in specialists' activity in the field of physical education and sports.

The physical education and sports teacher is responsible for setting tasks, planning, executing, controlling, and evaluating the physical education and sports lesson.

The didactic approach's design refers to the ordering of the objectives to obtain the most efficient results. By design, the teacher orients his actions taking into account the general objectives of the planning.

The role of the teacher in designing and organizing the activity is significant. For a good design, the field specialist must have an overview of the entire curriculum allocated to a year of study.

As mandatory planning documents, in all educational disciplines are:

a) the calendar plan, which is considered an administrative document that associates reference objectives and contents with the time allocation considered optimal by the teacher during a semester / school year;

b) designing learning units, considered to be open and flexible teaching structures.

In addition to these documents, it is necessary to develop another document called "annual staggering of learning units" in physical education and sports. This is the first planning document developed, based on which the other two will be developed. This document may also have an annex called the "centralization chart" on the lesson's distribution of learning units.

The entire training activity to design the design documents in physical education and sports must be carried out according to the specialized programs in force, which is an essential part of the National Curriculum. The current school curricula emphasize the importance of the regulatory role of objectives on two primary levels:

a) framework objectives;

b) specific competencies.

The other components of the program have as main goal the achievement of the students' objectives.

The school curriculum describes the educational offer of a particular discipline for a determined school path.

The framework objectives are objectives with a high degree of generality and complexity, and they refer to the formation of capacities and skills generated by the specifics of the discipline of physical education and sports and are pursued over several years of study.

The specific competencies specify the expected learning outcomes and follow the progression in the capacity building and the acquisition of knowledge of the students from one year to another in physical education and sports.

\section{REFERENCES}

Ardelean, M., Neagu, N., \& Szabo, D.A., (2020). Pedagogical considerations regarding the structure of high school lower cycle syllabuses, for the "Theoretical Sports Training" school subject (Note I). Health, Sports \& Rehabilitation Medicine, Vol. 21, Isssue 4, 256-259. https://doi.org/10.26659/pm3.2020.21.4.256

Bailey, R., Armour, K., \& Kirk, D. (2009). The educational benefits claimed for physical education and school sport: an academic review. Research Papers in Education, Vol. 24, Issue 1, 1-27.

Berke, P., \& Godschalk, D. (2009). Searching for a good plan: A meta-analysis of plan quality studies. Journal of Planning Literature, Vol. 23, Issue 3, 227-240. 
Bocos, M., \& Jucan, D. (2008). The fundamentals of pedagogy. The theory and methodology of curriculum. Bucharest: Paralela 45.

Bulger, S.M., \& Housner, L.D. (2009). Relocating from easy street: Strategies for moving physical education forward. Quest, Vol. 61, 442-469.

Cristea, S. (2006). Curriculum pedagogic. Bucharest: Didactic and Pedagogical.

Fey, J. (2011). Dance Units for Middle Schools. Champaign, IL: Human Kinetics.

Goudas, M., \& Giannoudis, G. (2008). A team-sports-based life-skills program in a physical education context. Learning and Instruction, Vol. 18, Issue 6, 528-536.

Jones, R.L., Armour, K.M., \& Potrac, P. (2003). Constructing expert Knowledge: A case study of a top-level professional soccer coach. Sport, Education and Society, Vol. 8, Issue 2, 213-29.

Liersch, S., Henze, V., Röbl, M., Schnitzerling, J., Suermann, T., Mayr, E., Krauth, C., \& Walter, U. (2011). Forty-five minutes of physical activity at school each day? Curricular promotion of physical activity in grades one to four. Journal of Public Health, Vol. 19, Issue 4, 329-338.

Mosston, M., \& Ashworth, S. (2008). Teaching Physical Education. First Online Edition. London: Pearson Education.

Opstoel, K., Chapelle, L., Prins, F. J., Meester, A. D., Haerens, L., Tartwijk, J., \& Martelaer, K. (2020). Personal and social development in physical education and sports: a review study. European Physical Education Review, Vol. 26, Issue 4, 797-813.

Popa, C.O., Schenk, A., Rus, A., Szasz, S., Suciu, N., Szabo, D.A., \& Cojocaru, C. (2020). The Role of Acceptance and Planning in Stress Management for Medical Students. Acta Marisiensis - Seria Medica, Vol. 66, Issue 3, 101-105.

Redmon, K., Foran, A., \& Dwyer, S. (2010). Quality lesson plans for outdoor education. Champaign, IL: Human Kinetics.

Ryan, D.B. (2011). Reading through a plan. Journal of the American Planning Association, Vol. 77, Issue 4, 309-327.

Sáenz-López, P., Almagro, B.J., Ibáñez, S. (2011). Describing Problems Experienced by Spanish Novice Physical Education Teachers. The Open Sports Sciences Journal, Vol. 4, 1-9. doi: 10.2174/1875399X01104010001

Salvador, C., Chiva, O., \& Fazio, A. (2016). Características del aprendizaje integrado de contenidos de Educación Física y Lengua extranjera. Retos, Vol. 29, 120-125.

Sopa, I.S., \& Szabo, D.A. (2015). Testing agility and balance in volleyball game. Discobolul Physical Education, Sport and Kinetotherapy Journal, Vol. XI, Issue 3(41), 167-174.

Stănescu, M. (2009). The didactics of physical education. Bucharest: ANEFS.

Stănescu, M. (2013). Planning physical education - from theory to practice. Procedia Social and Behavioral Sciences, Vol. 76, 790-794.

Szabo, D.A. (2015a). Modalities of Using the Information Provided by the Statistical Program Click and Scout for Improving the Outside Hitters Service Efficiency in Volleyball Game. The European Proceedings of Social \& Behavioral Sciences EpSBS, Vol. XI, 341-347. doi: http://dx.doi.org/10.15405/epsbs.2016.06.47

Szabo, D.A. (2015b). Study on improving the service unforced errors in volleyball game by using a statistical software. Conference proceedings of eLearning and Software for Education (eLSE), Issue 3, 320-326.

Szabo, D.A., \& Magdaş, L. (2014). Increasing the defensive efficiency in volleyball using the statistical program "Click\&Scout". Conference proceedings of eLearning and Software for Education (eLSE), Issue 1, 223-228. 
Szabo, D.A., \& Sopa, I.S. (2015). Study on the Interpretation of the Results in a Volleyball Game by Using a Specific Program of Statistics. Procedia Social and Behavioral Sciences, Vol. 180C, Elsevier Publication, 1357-1363.

Szabo, D.A., Neagu, N., Teodorescu, S., \& Sopa, I.S. (2019). Modalities of exploatation the information provided by the Click \& Scout statistical program in preparing volleyball attack players. International Journal of Applied Exercise Physiology, Vol. 8, Issue 2.1, 852-859.

Szabo, D.A., Neagu, N., \& Sopa, I.S., (2020). Research regarding the development and evaluation of agility (balance, coordination and speed) in children aged 9-10 years. Health, Sports \& Rehabilitation Medicine, Vol. 21, Issue 1, 33-40. https://doi.org/10.26659/pm3.2020.21.1.33

Tulbure, R.E., Neagu, N., \& Szabo, D.A., (2020). Comparative study on the development of the motor skill (strength) through the circuit method versus dynamic games in physical education classes. Health, Sports \& Rehabilitation Medicine, Vol. 21, Issue 4, 223-230. https://doi.org/10.26659/pm3.2020.21.4.223

Viciana, J., \& Zabala, M. (2004). Un estudio descriptivo sobre cómoplanifican los profesores de Educación Física. International Congress of AIESEP 2002. Preparación profesional y necesidades sociales (pp. 732-739). A Coruña, Spain: AIESEP.

Vicina, J., \& Mayorga-Vega, D. (2018). The three-axes model of planning in physical education. Retos, Vol. 33, 226-232. 